\title{
Developments in the Ni-Nb-Zr Amorphous Alloy Membranes
}

\author{
S. Sarker ${ }^{1}$, D. Chandra ${ }^{1 *}$, M. Hirscher ${ }^{2}$, M. Dolan ${ }^{3}$, D. Isheim ${ }^{4}$, J. Wermer $^{5}$, D. Viano ${ }^{3}$, M. Baricco ${ }^{6}$, Terrence \\ J. Udovic ${ }^{7}$, D. Grant ${ }^{8}$, O. Palumbo ${ }^{9}$ and A. Paolone ${ }^{9}$, and R. Cantelli ${ }^{10}$
}

\author{
${ }^{1}$ Mat. Sci. \& Engr., University of Nevada, Reno, MS 388, Reno NV 89557 USA \\ ${ }^{2}$ Max-Planck-Institut für Intelligente Systeme, Heisenbergstrasse 3D-70569 Stuttgart, Germany \\ ${ }^{3}$ CSIRO, QCAT, Energy, 1 Technology Court, Pullenvale QLD 4069 Australia \\ ${ }^{4}$ NUCAPT, Mat. Sci. \& Engr., 2220 N. Campus Dr. Northwestern University, Evanston IL 60208 US \\ ${ }^{5}$ Los Alamos National Laboratory, Los Alamos, NM 875451 USA \\ ${ }^{6}$ Department of Chemistry and NIS, University of Turin, Via P. Giura, 9 I-10125 Torino, Italy \\ ${ }^{7}$ National Institute of Standards and Technology, Gaithersburg, Maryland 20899 USA \\ ${ }^{8}$ University of Nottingham, Room B67 Coates University Park Nottingham NG7 2RD UK \\ ${ }^{9}$ CNR-ISC, U.O.S. La Sapienza, Piazzale A. Moro 5, 00185 Roma, Italy \\ ${ }^{10}$ Dipartimento di Fisica, Sapienza Università di Roma, Piazzale Aldo Moro, 5, 00185 Roma, Italy \\ *Corresponding author: dchandra@unr.edu (775-784-4960)
}

\begin{abstract}
Most of the global $\mathrm{H}_{2}$ production is derived from hydrocarbon-based fuels, and efficient $\mathrm{H}_{2} / \mathrm{CO}_{2}$ separation is necessary to deliver a high purity $\mathrm{H}_{2}$ product. Hydrogen-selective alloy membranes are emerging as a viable alternative to traditional pressure swing absorption processes as a means for $\mathrm{H}_{2} / \mathrm{CO}_{2}$ separation. These membranes can be formed from a wide range of alloys, and those based on Pd are the closest to commercial deployment. The high cost of $\mathrm{Pd}$ (USD $31,000 \mathrm{~kg}^{-1}$ ), however, is driving the development of less-expensive alternatives, including inexpensive amorphous $\left(\mathrm{Ni}_{60} \mathrm{Nb}_{40}\right)_{100-\mathrm{x}} \mathrm{Zr}_{\mathrm{x}}$ alloys. Amorphous alloy membranes can be fabricated directly from the molten state into continuous ribbons via melt spinning, and depending on the composition, can exhibit relatively high hydrogen permeability between 473 and $673 \mathrm{~K}$. Here we review recent developments in these low-cost membrane materials, especially with respect to permeation behavior, electrical transport properties, and understanding of local atomic order. In a quest to further understand the nature of these solids, atom probe tomography has been performed, revealing amorphous $\mathrm{Nb}$-rich and $\mathrm{Zr}$-rich clusters embedded in, majority $\mathrm{Ni}$ matrix, whose compositions deviated from the nominal overall composition of the membrane. This research is supported by US DOE-NNSA grant, US DE-NA0002004).
\end{abstract}

\section{Introduction}

The bulk of global $\mathrm{H}_{2}$ production still originates from the conversion of hydrocarbon fuels such as coal, crude oil, natural gas and biomass, and the co-production of $\mathrm{CO}_{2}$ necessitates a $\mathrm{H}_{2} / \mathrm{CO}_{2}$ separation process to deliver $\mathrm{H}_{2}$ of the desired purity to downstream processes [1,2]. Pressure swing adsorption (PSA) is a reliable, established technique for this separation, but is less than ideal from an efficiency and size perspective. Alloy membranes offer the advantage of compact size and continuous separation, but are currently limited to small-scale, niche applications. For example, crystalline Pd and Pd-Ag (100 - $200 \mu \mathrm{m}$ thickness) membranes have been employed for several decades to obtain ultrapure $\mathrm{H}_{2}$ [3-9]. The reported hydrogen selectivity and permeability of these membranes varies widely, but $\mathrm{H}_{2}$ flux values in excess of $1 \mathrm{~mol} \mathrm{~m}^{-2} \mathrm{~s}^{-1}$ have been reported [10]. A limitation of Pd-based membranes is the potential for hydride formation under certain operating conditions, and this can lead to eventual failure of the membrane because of increased brittleness. But perhaps the greatest barrier to further deployment of Pd membrane technology is the high price of Pd metal: the cost of Pd was USD $160 \mathrm{oz}^{-1}$ in April 2003, and the prices are rising steadily: in September 2015, the cost was USD $697 \mathrm{oz}^{-1}$. This is driving the development of less-expensive alternative membrane materials. Steward's review of hydrogen permeability [11] showed several metals have equivalent or greater permeability than Pd. Furthermore, many of these metals, such as $\mathrm{Ni}, \mathrm{Co}, \mathrm{Nb}, \mathrm{Zr}$, cost in the range of USD 1-3 $\mathrm{oz}^{-1}$, making them of great interest as potential Pd-alternatives.

Amorphous alloys formed from a combination of Ni and one or more early transition metals (ETMs) show great promise for this application. Amorphous alloy membranes are formed directly from the molten state via a technique known as melt spinning, in which the molten alloy is rapidly solidified on the surface of a rolling copper wheel, acting as heat sink. This technique produces continuous ribbons, typically 20 to $60 \mu \mathrm{m}$ thick, and $\sim 25 \mathrm{~mm}$ wide.

One of the main barriers to the use of amorphous membranes is their propensity to crystallize during long-term operation at elevated temperatures, a process which increases atomic density and leads to reduction in hydrogen diffusion pathways. In addition, crystallization often induces brittleness in the ribbon, limiting as a consequence the operating conditions. In this review, we explore this phenomenon further by presenting studies that have been 
performed on $\mathrm{Ni}-\mathrm{Nb}-\mathrm{Zr}$ amorphous membrane alloys regarding permeation, electrical, chemical homogeneity and local atomic order, and mechanical properties.

\section{Brief History of Development of Amorphous Alloy Membranes}

The very first amorphous AuSi alloy was prepared at California Institute of Technology in 1960 by Klement et al. [12]. Since then, significant research advances were made on understanding of the nature of membranes in Japan; particularly at the Tohuku University and AIST. The amorphous membranes are generally fabricated by melt spinning methods, with critical cooling rates $>10^{5} \mathrm{~K} \mathrm{sec}^{-1}$. In the late 1980ties, Inoue [13-14] discovered glass forming ability (GFA) and formation of bulk metallic glasses (BMG) in La-Al-Ni and La-Al-Cu by casting in copper molds at very slow rates $<100 \mathrm{~K} \mathrm{sec}^{-1}$. Inoue [13] also established important parameters for the formation of BMG in which three or more components are needed with atomic size ratio $>12 \%$, and negative heat of mixing. The selection of compositions for metallic glass formation can be driven by thermodynamic arguments [15] and metallic glasses with various compositions have been produced up to now. The BMG multicomponent alloys are used for structural and other applications, whereas thin amorphous alloys discussed in this paper are mainly used in magnetic applications and membranes for hydrogen separation.

Several membrane types can be employed for the separation of $\mathrm{H}_{2}$ from $\mathrm{CO}_{2}$, namely ceramic ion transport membranes, inorganic micro-porous membranes, and alloy membranes, both crystalline and amorphous. Several notable reviews on these various membrane technologies have been published. In 2006, Phair and Donelson [16] reviewed developments in non-palladium alloy membranes related to design and preparation of alloys for hydrogen permeability, and critical performance features of $\mathrm{Ti}, \mathrm{Zr}$, $\mathrm{Hf}$ and $\mathrm{V}, \mathrm{Nb}$, Ta group of elements and alloys. Phair and Badwal [17] reviewed materials for separation of membranes for hydrogen and oxygen production, $\mathrm{H}_{2}$ and $\mathrm{CO}_{2}$ separation, and power generation. In 2006, Dolan et al. [18] published a comprehensive review on hydrogen selective amorphous membranes. They reported on significant issues related to amorphous membranes with respect to crystallization during long-term sustainability of amorphous membranes at elevated temperatures $(673 \mathrm{~K})$. They also discussed factors affecting diffusion rates, influence of hydrogen on thermal stability site symmetry and energies. Ockwig and Nenoff [19] reviewed different types of hydrogen separation membranes and reported hydrogen permeabilities of $\mathrm{VCrTi}$, NiAl, VAl, VNiAl, NbMo, NbPd, NbTiNi, VTi, VCo, Zr-Ti-Ni and other alloys, in a temperature range of 475 to $923 \mathrm{~K}$.

The exploration of hydrogen absorption properties of Ni-based amorphous alloys started in 1981. Spit et al. [20] Aoki et al. [21] both presented hydrogen absorption properties amorphous Ni-Zr alloys. More hydrogen separation membranes were developed in 1990 s such as $\mathrm{Pd}_{73.2} \mathrm{Si}_{18} \mathrm{M}_{8.8}$ (M= $\left.\mathrm{Ag}, \mathrm{Cu}, \mathrm{Cr}, \mathrm{Fe}, \mathrm{Ni}\right), \mathrm{Ni}_{60} \mathrm{Zr}_{40}$ and other alloys [22-26]. The pioneering work on permeation through the Ni-based amorphous alloys was first reported by Hara et al. [27] who produced melt spun ribbons of $\mathrm{Ni}_{64} \mathrm{Zr}_{36}$ for separation of hydrogen from $\mathrm{CO}_{2}$. They found permeation rates greater than $1 \times 10^{-9} \mathrm{molm}^{-1} \mathrm{~s}^{-1} \mathrm{~Pa}^{-0.5}$ yielding high purity $\mathrm{H}_{2}$, without need for a catalytic $\mathrm{Pd}$ overlayer.

\section{Amorphous Ni-based membranes}

The Ni-Nb-Zr alloy system is the most widely studied from the perspective of hydrogen separation. A summary plot of hydrogen permeation through Ni-Nb-Zr alloy, with alloying elements such as $\mathrm{Ta}$, $\mathrm{Co}$, $\mathrm{Hf}$ and others, is shown in Figure 1; selected Pd-based alloys are included as reference. Please note that single data points found in literature, appear as double circled symbol in this Figure 1. In general, the permeation rates of $\mathrm{Ni}-\mathrm{Nb}-\mathrm{Zr}$ membranes are approximately in the range of $5 \times 10^{-8} \mathrm{~mol} \mathrm{~m}^{-1} \mathrm{~s}^{-1} \mathrm{~Pa}^{-0.5}$ and $1 \times 10^{-10} \mathrm{~mol} \mathrm{~m}^{-1} \mathrm{~s}^{-1} \mathrm{~Pa}^{-0.5}$.

The addition of $\mathrm{Nb}$ to $\mathrm{Ni}-\mathrm{Zr}$ alloys brings the beneficial effects of increased crystallization temperature and fracture strength [28], and reduced susceptibility to hydrogen embrittlement [29]. Kimura et al. [28] produced wide, high quality, amorphous $\mathrm{Ni}-\mathrm{Nb}-\mathrm{Zr}$ melt spun ribbons of $\left(\mathrm{Ni}_{0.50} \mathrm{Nb}_{0.50}\right)_{100-\mathrm{x}} \mathrm{Zr}_{\mathrm{x}}$ where $\mathrm{x}=10,20,30,40$, and $\mathrm{Ni}_{60} \mathrm{Nb}_{40-\mathrm{x}} \mathrm{Zr}_{\mathrm{x}}$ where $\mathrm{x}=10,20,30,40$, and measured thermal and mechanical properties, but did report any permeation results.

In 2003, Yamaura et al [29] investigated hydrogen permeation membranes of $\left(\mathrm{Ni}_{0.60} \mathrm{Nb}_{0 \cdot 40}\right)_{100-\mathrm{x}} \mathrm{Zr}_{\mathrm{x}}(\mathrm{x}=0-40$ at.\%) and showed comparable permeation rates with Pd and Pd-Ag at temperature 573 to $673 \mathrm{~K}$. Also, in 2003, Hara et al. [30] explored the possibility of making ribbons of Ni-Zr with Ti and $\mathrm{Hf}$ additions and found that permeabilities of $\mathrm{Ni}-\mathrm{Zr}$ alloys decreased by the addition of Ti or $\mathrm{Hf}$ due to increased activation energies. Hara et al. continued studies on $\mathrm{Zr}_{36-\mathrm{x}} \mathrm{Hf}_{\mathrm{x}} \mathrm{Ni}_{64}(0 \leq \mathrm{x} \leq 36)$ and observed that the ribbons did crack during tests that lasted for few days in temperature range of 473 to $623 \mathrm{~K}$, but reported that the hydrogen solubility parameters closely followed Sieverts' law [31]. 
Yamaura et al. [32] studied formabilities of ribbons, and performed exhaustive work by adding different alloying elements to $\left(\mathrm{Ni}_{0.60} \mathrm{Nb}_{0.40}\right)_{45} \mathrm{Zr}_{50} \mathrm{M}_{5}$ master alloy, where $\mathrm{M}=\mathrm{Ti}, \mathrm{Ta}, \mathrm{Sn}, \mathrm{Si}, \mathrm{Pd}, \mathrm{Cu}, \mathrm{Co}, \mathrm{Al}$, reporting high permeation rates of $2.3 \times 10^{-8}$ and $\left.2.5 \times 10^{-8} \mathrm{~mol} \mathrm{~m}^{-1} \mathrm{~s}^{-1} \mathrm{~Pa}^{-0.5}\right)$ for $\mathrm{Cu}$ and $\mathrm{Co}$ additions; noting that pure $\mathrm{Pd}$ has a permeation rate of $1.0 \times 10^{-8}\left(\mathrm{~mol} \mathrm{~m}^{-1} \mathrm{~s}^{-1} \mathrm{~Pa}^{-0.5}\right)$ at $673 \mathrm{~K}$. The permeability with the addition of $\mathrm{P}\left(2.5 \times 10^{-8} \mathrm{~mol}\right.$ $\mathrm{m}^{-1} \mathrm{~s}^{-1} \mathrm{~Pa}^{-0.5}$ ) was found to be the lowest. They also found that permeability is inversely proportional to the Vickers Hardness (VH); for example the $\mathrm{VH}$ of $\mathrm{Cu}, \mathrm{Co}, \mathrm{Pd}, \mathrm{Al}, \mathrm{P}$ are 460, 500, 510, 510, and $560 \mathrm{Hv}$, respectively.

Yamaura et al. [33] continued their studies on permeation rates of ternary alloy series $\left(\mathrm{Ni}_{0.60} \mathrm{M}_{0.40}\right)_{70} \mathrm{Zr}_{30}(\mathrm{M}=\mathrm{Ti}$, $\mathrm{Nb}, \mathrm{Hf}),\left(\mathrm{Ni}_{0.90} \mathrm{M}_{0.10}\right)_{70} \mathrm{Zr}_{30}(\mathrm{M}=\mathrm{Y}, \mathrm{Hf}, \mathrm{Ti}, \mathrm{Nb}, \mathrm{Ta})$, and $\mathrm{Ni}_{70-\mathrm{x} / 2} \mathrm{Nb}_{30-\mathrm{x} / 2} \mathrm{Zr}_{\mathrm{x}}(\mathrm{x}=10-60)$; and reported that addition of $\mathrm{Nb}$ improves hydrogen permeability. In one case, cast eutectic crystalline $\mathrm{Ni}_{30} \mathrm{Nb}_{40} \mathrm{Zr}_{30}, \mathrm{Ni}_{40} \mathrm{Nb}_{20} \mathrm{Zr}_{40}$, $\mathrm{Ni}_{30} \mathrm{Nb}_{39} \mathrm{Ti}_{31}$ alloy thick disks were reportedly by Ishikawa et al. [34] for hydrogen permeation, and surprisingly reported 2.9 times greater permeability than that of pure $\mathrm{Pd}$.

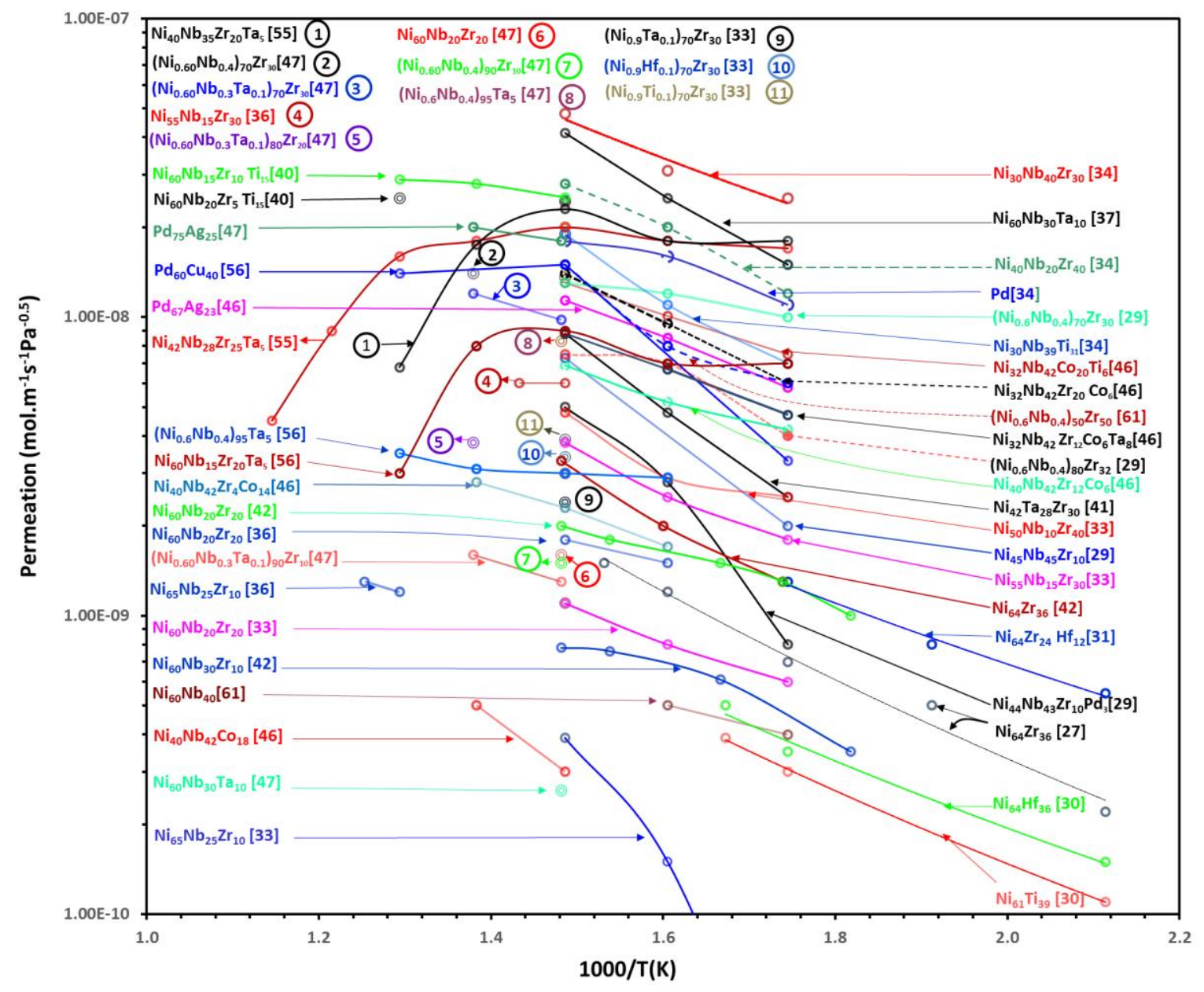

Figure 1. Summary of reported hydrogen permeability values for Ni-based amorphous alloy membranes and selected Pd-based alloys as reference materials

Cobalt has been explored as an alloying addition to Ni-Nb-Zr alloys by several groups. Shimpo et al. [35] investigated $\mathrm{Co}$ additions to the melt spun amorphous $\mathrm{Ni}-\mathrm{Nb}-\mathrm{Zr}$ alloys, and measured the permeability of $\left(\mathrm{Ni}_{0.60} \mathrm{Nb}_{0.40}\right)_{45} \mathrm{Zr}_{50} \mathrm{Co}_{5}$, reporting a value greater than that of conventional $\mathrm{Pd}-\mathrm{Ag}$ alloys. They also examined the durability of $\left(\mathrm{Ni}_{0.60} \mathrm{Nb}_{0.40}\right)_{55} \mathrm{Zr}_{40} \mathrm{Co}_{5}$ and $\left(\mathrm{Ni}_{0.60} \mathrm{Nb}_{0.40}\right)_{45} \mathrm{Zr}_{50} \mathrm{Co}_{5}$ at $573 \mathrm{~K}$ and found no change up to 100 hours at $573 \mathrm{~K}$, but above $673 \mathrm{~K}$ there was significant decay in permeation with time. Yamaura et al. [36] also reported a significant increase in hydrogen diffusivity in $\mathrm{Ni}_{65} \mathrm{Nb}_{25} \mathrm{Zr}_{10}$ and $\mathrm{Ni}_{60} \mathrm{Nb}_{20} \mathrm{Zr}_{20}$ alloys above glass transition temperature $\left(\mathrm{T}_{\mathrm{g}}\right)$.

In order to increase the crystallization temperature the introduction of tantalum into amorphous alloys has been explored by several groups. Kim et al. (2007) [37] compared hydrogen permeation of $\mathrm{Ni}_{60} \mathrm{Nb}_{30} \mathrm{Ta}_{30}$ with $\mathrm{Pd}_{60} \mathrm{Cu}_{40}$ at $673 \mathrm{~K}(0.6 \mathrm{MPa})$, and reported permeabilities of $4.1 \times 10^{-8}$ and $2.1 \times 10^{-8} \mathrm{~mol} \mathrm{~m}^{-1} \mathrm{~s}^{-1} \mathrm{~Pa}^{-0.5}$. The next year, Hara et al. [38] reported hydrogen solution properties of $\mathrm{Zr}_{36-\mathrm{x}} \mathrm{Hf}_{\mathrm{x}} \mathrm{Ni}_{64}(\mathrm{x}=0-36$ at. \%) at elevated temperatures (473 $-573 \mathrm{~K}$ ) by using the Sieverts method and found that permeability increased with increasing $\mathrm{Zr}$ content. The 
equilibrium hydrogen concentration did not obey Sieverts law, however, and was nearly linear with the quarter power determined using Kirchheim theory. Hara et al. [39] established a theory of permeability as a function of hydrogen pressure and developed equations for pressure dependent permeability from permeation tests. They also reported that the dissolution of hydrogen did not obey Sieverts' law (i.e., proportional to $\mathrm{P}^{0.5}$ ). In the same year, Lee and Fleury [40] measured hydrogen permeability of $\mathrm{Ni}_{60} \mathrm{Nb}_{15} \mathrm{Zr}_{10} \mathrm{Ti}_{15}\left(2.89 \times 10^{-8} \mathrm{~mol} \mathrm{~m}^{-1} \mathrm{~s}^{-1} \mathrm{~Pa}^{-0.5}\right)$ and $\mathrm{Ni}_{60} \mathrm{Nb}_{20} \mathrm{Zr}_{5} \mathrm{Ti}_{15}\left(2.50 \times 10^{-8} \mathrm{~mol} \mathrm{~m}^{-1} \mathrm{~s}^{-1} \mathrm{~Pa}^{-0.5}\right)$ at $673-773 \mathrm{~K}$, and reported 5 times larger permeability as compared binary $\mathrm{Ni}_{60} \mathrm{Nb}_{40}$ alloy membrane. Qiang et al. [41] conducted a detailed study of $\mathrm{Ni}_{42} \mathrm{Nb}_{28-\mathrm{x}} \mathrm{Zr}_{30} \mathrm{Ta}_{\mathrm{x}}(\mathrm{x}=0,7,14$, $21,28)$ and reported that substitution of $\mathrm{Nb}$ by $\mathrm{Ta}\left(\mathrm{Ni}_{42} \mathrm{Zr}_{30} \mathrm{Ta}_{28}\right)$ increased the thermal stability of alloy. The crystallization temperatures $\left(\mathrm{T}_{\mathrm{X}}\right)$ of $\mathrm{Ni}_{42} \mathrm{Zr}_{30} \mathrm{Nb}_{28}$ and $\mathrm{Ni}_{42} \mathrm{Zr}_{30} \mathrm{Ta}_{28}$ were 807 and $865 \mathrm{~K}$ respectively, but although $\mathrm{T}_{\mathrm{X}}$ increased with $\mathrm{Ta}$ addition, the permeability decreased.

Dolan et al. [42] reported hydrogen separation by Ni- ETM (ETM = Early Transition Metal) amorphous membranes at the comparatively higher temperature of $673 \mathrm{~K}$. They compared thermal stability and durability, hydrogen permeation of Ni-based amorphous alloys and suggested proper balance of eutectic alloy with early transition metal was suitable to obtain both permeability and thermal stability. According to their thermal analysis of binary and ternary Ni-ETM eutectic alloy by non-isotherm DSC, crystallization temperature increases with addition of early transition metal as follows $\mathrm{Ta}>\mathrm{Nb}>\mathrm{Hf}>\mathrm{Zr}>\mathrm{Ti}$, i.e., Ta and $\mathrm{Nb}$ maximize thermal stability.

It is well known that $\mathrm{Zr}$ additions to $\mathrm{Ni}-\mathrm{Nb}$ amorphous alloys lead to greater $\mathrm{H}$ solubility [42]; this had significant impact on further investigation of $\mathrm{Ni}_{60} \mathrm{Nb}_{40-\mathrm{x}} \mathrm{Zr}_{\mathrm{x}}$ series for hydrogen separation applications. Dolan et al. [43] continued their studies on $\mathrm{Ni}-\mathrm{Zr}$ alloys to understand the glass-forming ability (GFA) of $\mathrm{Ni}_{64} \mathrm{Zr}_{36-\mathrm{x}} \mathrm{M}_{\mathrm{x}}, \mathrm{x}=10$ at. $\%$ $\mathrm{M}=\mathrm{Ti}, \mathrm{Nb}, \mathrm{Mo}$, Hf with reasonable success, but found some dimensional instabilities. The alloy ribbons with Ta and $\mathrm{W}$ additions produced fragmented ribbons with crystalline inclusions, thus they become brittle and are not recommended for further studies. Thermal stability studies showed that most of the alloys exhibited $\mathrm{T}_{\mathrm{X}}$ values in the range of 567 to $586 \mathrm{~K}$, except for the $\mathrm{Nb}$-containing alloy $(602 \mathrm{~K})$, which was attributed to high bond valence and slightly smaller radius of $\mathrm{Nb}$. The hydrogen permeability measurement showed that $\mathrm{Ni}_{64} \mathrm{Zr}_{36}$ have higher permeability than $\mathrm{Ni}_{64} \mathrm{Zr}_{26} \mathrm{Nb}_{10}$ and $\mathrm{Ni}_{64} \mathrm{Zr}_{26} \mathrm{Ti}_{10}$ at $773 \mathrm{~K}$. Comparing all these data from GFA, thermal stability and hydrogen permeability they conclude $\mathrm{Ni}-\mathrm{Nb}-\mathrm{Zr}$ system is the most important system for hydrogen selective membrane reactor.

\section{Catalytic Dissociation of Hydrogen Molecules by Pd and Ni Coatings on Non-Pd based membranes:}

The suitability of $\mathrm{Pd}$ as a membrane material rests more with its favorable surface properties than the rate of $\mathrm{H}$ transfer through the bulk metal. $\mathrm{Pd}$ is among the most active catalysts for $\mathrm{H}_{2}$ dissociation, the essential first step in hydrogen transfer across an alloy membrane, meaning that a single layer of $\mathrm{Pd}$ or a Pd-based alloy can act as a H-selective membrane. Although Steward's review [11] shows that many metals exhibit significantly greater permeability than $\mathrm{Pd}$, their unfavorable surface properties mean they can only function as a membrane with addition of a thin Pd catalytic over-layer.

This also holds for many amorphous alloy membranes. $\mathrm{Ni}$ is known to be a highly active catalyst for $\mathrm{H}_{2}$ dissociation [44], and Hara [27] showed that amorphous $\mathrm{Ni}_{64} \mathrm{Zr}_{36}$ contains sufficient $\mathrm{Ni}$ to enable hydrogen permeation without need for an additional catalytic overlayer of Pd. Further examination by Spit et al. [20] and Adibhatla [45] found Ni segregation on the surface of the alloy that promoted catalytic activity. Ni can also be reduced by hydrogen at normal operating temperatures, but $\mathrm{Ni}$ is not resistant to sulfur dioxide, carbon monoxide or moisture. At reduced Ni contents, however, oxide formation by the ETM components renders the surface inactive, necessitating application of $\mathrm{Pd}$. In general, elements like $\mathrm{Nb}$, Ta, or $\mathrm{Zr}$ used in these non-Pd containing membranes always have an adherent oxide film which is not readily reduced under normal operating temperatures with hydrogen [46].

The Pd overlayer can influence thermal stability of the membrane, as inter-diffusion of Pd into the Ni-based alloy ribbons was observed in our studies [47] as well as by Buxbaum [48]. This diffusion can degrade the surface activity and can lead to the formation of impermeable compounds at the interface. More details can be found in Dolan's review [18]. In 2010, Yamaura and Inoue [49] conducted an interesting study on surface coatings of Pd and $\mathrm{Ni}$ on amorphous $\mathrm{Ni}_{40} \mathrm{Nb}_{20} \mathrm{Ta}_{5} \mathrm{Zr}_{30} \mathrm{Co}_{5}$. They sandwiched the amorphous alloy ribbon between $\mathrm{Pd}-\mathrm{Pd}, \mathrm{Ni}-\mathrm{Ni}$, $\mathrm{Pd}-\mathrm{Ni}$ (upstream-retentate side), and Ni-Pd (downstream-permeate side) coatings, showing that the Pd-coated retentate surfaces are resistant to poisoning by contaminant gases such as $\mathrm{H}_{2} \mathrm{~S}$ and others, while on the permeate side a simple Ni coating may be used, as there is presence of only highly pure $\mathrm{H}_{2}$ gas. Lewis et al. [50] showed that $\mathrm{Pd}-\mathrm{Au}$ coating were more resistant to $\mathrm{H}_{2} \mathrm{~S}$ contamination. Earlier studies on surface coatings of Ni were conducted by Chian et al. [51] in 2005 obtained reasonable permeation rates at $653 \mathrm{~K}$. 
To summarize, nearly all permeation studies of amorphous $\mathrm{Ni}-\mathrm{Nb}-\mathrm{Zr}$ membranes have been undertaken on membranes with a thin Pd over-layer on each surface. However, heat treating uncoated membranes under $\mathrm{H}_{2}$ results in precipitation of nanocrystalline $\mathrm{Ni}$, and slightly larger $\mathrm{Zr}$ particles, which help in catalyzing $\mathrm{H}_{2}$ dissociation [27, 20, 45 ]. This activation method has been employed when measuring hydrogen absorption via the Sieverts' method, and when measuring thermal properties of hydrided alloys via differential scanning calorimetry.

\section{Crystallization in Ni-Nb-Zr alloy membranes}

An important consideration for amorphous alloy membranes is thermal stability; the metastable amorphous state must be maintained during sustained operation at elevated temperature. Thermal stability can be quantified through the glass transition $\left(\mathrm{T}_{\mathrm{g}}\right)$ and crystallization $\left(\mathrm{T}_{\mathrm{X}}\right)$ temperatures, as well as by the activation energy of crystallization which can be measured using the approach of Kissinger [52] and Ozawa [53].

Many studies have been performed over the years to measure these parameters and there is a clear trend of refractory elements increasing $\mathrm{T}_{\mathrm{g}}$ and $\mathrm{T}_{\mathrm{X}}$. Several studies have been performed on these alloys by on different types of membranes [29, 36, 41]. We examined [54] phase transformation and crystallization kinetics of amorphous $\mathrm{Ni}_{60} \mathrm{Nb}_{20} \mathrm{Zr}_{20}$, finding that the activation energies for crystallization using Johnson-Mehl-Avrami (JMA) and Kissinger and Ozawa equations of 500 and $490 \mathrm{~kJ} \mathrm{~mol}^{-1}$ respectively. The Avrami exponent of $2.92-$ 2.47 indicated a diffusion-controlled three dimensional growth mechanism of a single crystalline phase whose structure matched that of a $\mathrm{Ni}_{10} \mathrm{Zr}_{7}$ alloy.

In 2010, Jayalakshmi et al. [55] studied the Ni-Nb-Zr-Ta alloys of two compositions and performed x-ray diffraction, mechanical tests, and permeation studies. Jayalakshmi et al. [56] (2012) continued her and this time she emphasized corrosion properties of amorphous $\mathrm{Ni}_{60} \mathrm{Nb}_{40}$ with alloying additions of $\mathrm{Zr}$, Ta, Co. They found that these alloys have excellent embrittlement resistance at $\mathrm{H} / \mathrm{M}=0.8$, and also comparable permeability of $\mathrm{Ni}$ $\mathrm{Nb}$ with $\mathrm{Pd}-\mathrm{Cu}$ alloy in the range $557-773 \mathrm{~K}$. They also suggested that $\mathrm{Ni}-\mathrm{Nb}$ based amorphous alloy membranes could be used as bipolar plates for proton exchange membrane fuel cell (PEMFC) due to excellent corrosion resistance and passive current density. This is a potential new application for a material which has been studied almost exclusively for its magnetic and hydrogen permeation properties.

It is generally agreed that $\mathrm{Nb}$ has a beneficial effect on the mechanical stability of amorphous $\mathrm{Ni}-\mathrm{Nb}-\mathrm{Zr}$ alloys. We believe that the toughness of the material is controlled by $\mathrm{Ni}$ and $\mathrm{Nb}$, but $\mathrm{Zr}$ contributes to solubility of hydrogen in the alloy ribbon. It appears that cobalt additions also reduce the brittleness of the membrane. There are sufficient studies related to the crystallization temperatures of these amorphous membranes. Alloying additions of $\mathrm{Ta}, \mathrm{Hf}, \mathrm{Nb}$, and $\mathrm{Ti}$ do improve the thermal stability and increase crystallization temperature, but permeabilities are not enhanced, although these membranes have excellent corrosion properties even in presence of hydrogen.

\section{Mechanical Properties}

Mechanical properties are of significant importance as membranes require sufficient strength to withstand large trans-membrane pressures, and while amorphous alloys are renowned for exhibiting high strength, the absorption of hydrogen can lead to embrittlement and mechanical failure under typical operating conditions. The mechanical behavior of amorphous $\mathrm{Ni}-\mathrm{Nb}-\mathrm{Zr}$ ribbons specifically has not been extensively investigated. In general, there is little plasticity in these ribbons, and stress-strain behavior is ceramic-like, however the ribbons are flexible when unloaded. More importantly, we are interested in the behavior of these ribbons under load with hydrogenation to simulate permeation conditions. Jayalakshmi et al. [57] reported a significant reduction of mechanical properties in $\mathrm{Zr}_{50} \mathrm{Ni}_{27} \mathrm{Ni}_{18} \mathrm{Co}_{5}$ and $\mathrm{Ni}_{59} \mathrm{Zr}_{16} \mathrm{Ti}_{13} \mathrm{Nb}_{7} \mathrm{Sn}_{3} \mathrm{Si}_{2}$ amorphous alloys upon hydrogenation, observing no structural and mechanical change at up to $\sim 16$ at $\% \mathrm{H}$, but rapid crystallization was observed above 16 at.\% $\mathrm{H}$.

Paglieri et al. [47] examined $\mathrm{Ni}_{40} \mathrm{Nb}_{20} \mathrm{Zr}_{20},\left(\mathrm{Ni}_{0 \cdot 60} \mathrm{Nb}_{0 \cdot 40}\right)_{100-\mathrm{x}} \mathrm{Zr}_{\mathrm{x}}$ and $\left(\mathrm{Ni}_{0.60} \mathrm{Nb}_{0.40} \mathrm{Ta}_{0.1}\right)_{100-\mathrm{x}} \mathrm{Zr}_{\mathrm{x}}(\mathrm{x}=0$ to 30 at.\%) alloys, finding that hydrogen solubility and permeability increased, while the fracture resistance decreased, with increasing $\mathrm{Zr}$ content. Ta addition decreased hydrogen permeability relative to the equivalent Ta-free alloys, but also increased the thermal stability. All alloys examined experienced a significant decrease in permeability during extended testing between 673 and $723 \mathrm{~K}$, suggesting a structural change over time.

More recently, Zhao et al. [58] used the nano indentation method to investigate the influence of dissolved $\mathrm{H}$ on shear yield strength and shear transformation zone volume of $\mathrm{Ni}_{45} \mathrm{Nb}_{30} \mathrm{Zr}_{25}, \mathrm{Ni}_{33} \mathrm{Nb}_{22} \mathrm{Zr}_{40} \mathrm{Co}_{5}, \mathrm{Ni}_{27} \mathrm{Nb}_{18} \mathrm{Zr}_{50} \mathrm{Co}_{5}$ and $\mathrm{Ni}_{35} \mathrm{Nb}_{30} \mathrm{Zr}_{15} \mathrm{Ti}_{10} \mathrm{Fe}_{5} \mathrm{Co}_{5}$. The observations were not consistent across all alloys, with the shear yield strength increasing and shear transformation zone volume decreasing in the $\mathrm{Zr}$-rich alloys $\left(\mathrm{Ni}_{33} \mathrm{Nb}_{22} \mathrm{Zr}_{40} \mathrm{Co}_{5}\right.$ and $\left.\mathrm{Ni}_{27} \mathrm{Nb}_{18} \mathrm{Zr}_{50} \mathrm{Co}_{5}\right)$, while the opposite effect was observed in the $\mathrm{Zr}$-poor alloys $\left(\mathrm{Ni}_{45} \mathrm{Nb}_{30} \mathrm{Zr}_{25}\right.$ and $\mathrm{Ni}_{35} \mathrm{Nb}_{30} \mathrm{Zr}_{15} \mathrm{Ti}_{10} \mathrm{Fe}_{5} \mathrm{Co}_{5}$ ). Zhao et al. [59] also observed softening in $\mathrm{Zr}$-poor alloys, attributed to the mobile 
hydrogen in the membrane. In the $\mathrm{Zr}$-rich alloys, $\mathrm{H}$ absorption led to hardening as $\mathrm{H}$ became trapped inside $\mathrm{Zr}$ sites, resulting in a densely packed structure.

Palumbo's [60] dynamic mechanical spectroscopy study of $\left(\mathrm{Ni}_{0.60} \mathrm{Nb}_{0.40}\right)_{100-\mathrm{x}} \mathrm{Zr}_{\mathrm{x}}(\mathrm{x}=20$ and 30 at. \%) membranes found that the elastic modulus changed sharply between $445-525 \mathrm{~K}$ for $\mathrm{x}=20$ at $\%$ and $423-473 \mathrm{~K}$ for $\mathrm{x}=30$ at $\%$, suggesting an amorphous to amorphous phase transition as function of temperature. The modulus of hydrogenated membranes strongly indicated that nano-sized $\mathrm{Zr}$ hydrides form and dissolve as a function of temperature, and therefore the elastic properties of the amorphous materials display a dramatic variation around these temperatures.

\section{Local Atomic order in the Ni-Nb-Zr Alloy Membranes}

The absence of any structural features or long-range ordering presents a major hurdle a full understanding of amorphous alloys, and limits the effectiveness of traditional techniques such as microscopy or diffraction. Hydrogen permeation through these alloy membranes are controlled by five important parameters, namely hydrogen solubility, hydrogen diffusivity, atomic arrangement in the membrane, probable location of hydrogen in the membrane, and mobile and trapped hydrogen sites. The first two parameters can be easily measured; the problem is the difficulty in determining the rest of the parameters in the amorphous materials. Recent work aimed at understanding short-range atomic ordering has greatly enhanced our understanding of these materials.

Yamaura et al. [61], Sakurai et al. [62], Oji et al.[63-64] Fukuhara et al. [65], Matsuura et al. [66], Fujima et al. [67] performed x-ray studies including, RDF, EXAFS, XANES and molecular dynamic calculations which made significant contribution towards understanding of the local atomic order of these alloy membranes. They determined coordination number, arrangement of atoms in the coordination polyhedra, and interatomic distances between atoms. More studies were performed using first-principles molecular dynamics calculations; thus the Japanese group made significant advances in understanding the nature of amorphous $\mathrm{Ni}-\mathrm{Nb}-\mathrm{Zr}$ by applying the above techniques. The local atomic structure of $\left(\mathrm{Ni}_{0.60} \mathrm{Nb}_{0 \cdot 40}\right)_{100-\mathrm{x}} \mathrm{Zr}_{\mathrm{x}}(\mathrm{x}=0-50$ at.\%) melt spun ribbons by $\mathrm{XRD/RDF}$ analyses was reported by Yamaura et al. [61] X-ray diffraction analyses showed that the amorphous hump shifted to a lower angle with the increasing $\mathrm{Zr}$ content that led to an increase in average interatomic distances [36]. Hydrogenation of $\left(\mathrm{Ni}_{0.60} \mathrm{Nb}_{0.4}\right)_{70} \mathrm{Zr}_{30}$ and $\left(\mathrm{Ni}_{0.60} \mathrm{Nb}_{0.4}\right)_{50} \mathrm{Zr}_{50}$ increases $\mathrm{Zr}-\mathrm{Zr}$ interatomic distances thus allowing faster hydrogen permeation.

In 2009, Oji et al. [60-61] studied the effect of dissolved $\mathrm{H}$ on the local atomic configuration of $\mathrm{Ni}_{42} \mathrm{Nb}_{28} \mathrm{Zr}_{30}$ by $\mathrm{XAFS}$ and showed the local structure around $\mathrm{Ni}, \mathrm{Nb}$ and $\mathrm{Zr}$ atoms does not change upon $\mathrm{H}$ absorption. However, hydrogen charging in the higher $\mathrm{Zr}$ content, $\mathrm{Ni}_{36} \mathrm{Nb}_{24} \mathrm{Zr}_{40} \mathrm{H}_{11}$, alters the local structure by elongating $\mathrm{Zr}-\mathrm{Zr}, \mathrm{Zr}-\mathrm{Nb}$ and $\mathrm{Nb}-\mathrm{Ni}$ interatomic distances. They also reported that $\mathrm{Ni}_{36} \mathrm{Nb}_{24} \mathrm{Zr}_{40}$ has a distorted, 13 atom- $\mathrm{Ni}_{6} \mathrm{Zr}_{6} \mathrm{Nb}$ or $\mathrm{Ni}_{5} \mathrm{Nb}_{3} \mathrm{Zr}_{5}$-type icosahedra structure. Based on their XAFS results, Oji et al. concluded the $\mathrm{Ni}_{5} \mathrm{Nb}_{3} \mathrm{Zr}_{5}$ cluster is more favorable than other polyhedral structures. Oji et al. also concluded that in the $\mathrm{Ni}_{42} \mathrm{Nb}_{28} \mathrm{Zr}_{30}$ ternary alloy, $\mathrm{H}$ atom sites are only outside of the icosahedra cluster, and in $\mathrm{Ni}_{36} \mathrm{Nb}_{24} \mathrm{Zr}_{40}$ alloy hydrogen sites, $\mathrm{H}$ occupies sites both outside and inside of the cluster.

A tetrahedral hydrogen occupancy site with three $\mathrm{Zr}$ and one $\mathrm{Nb}$ atoms as a favorable configuration was also reported. In 2010, Fukuhara et al [65] reported more refined icosahedral cluster structures of $\mathrm{Ni}-\mathrm{Nb}-\mathrm{Zr}-\mathrm{H}$ glassy alloys by using first-principles molecular dynamics calculations and XANES measurements. Oji et al.'s [63-64] observation of distorted icosahedral $\mathrm{Ni}_{5} \mathrm{Zr}_{5} \mathrm{Nb}_{3}$ clusters, in which the hydrogen sites outside the cluster in $\mathrm{Ni}_{42} \mathrm{Nb}_{28} \mathrm{Zr} 30$, were confirmed by Fukuhara et al. [65]. In the case of $\mathrm{Ni}_{36} \mathrm{Nb}_{24} \mathrm{Zr}_{40}$ alloys, $\mathrm{H}$ occupies tetrahedral sites surrounded by $\mathrm{Zr}, \mathrm{Nb}$ and $\mathrm{Ni}$ atom clusters, causing an increase in the bond distance of $\mathrm{Zr}-\mathrm{Zr} / \mathrm{Zr}-\mathrm{Nb}$ and $\mathrm{Nb}-\mathrm{Ni}$. Matsuura et al. [66] reported on local atomic structural effects by hydrogenation of the $\left(\mathrm{Ni}_{0.60} \mathrm{Nb}_{0.40}\right)_{65} \mathrm{Zr}_{35}$ ribbon to form amorphous [ $\left.\left(\mathrm{Ni} .{ }_{60} \mathrm{Nb} .40\right)_{65} \mathrm{Zr}_{35}\right]_{92.2} \mathrm{H}_{7.8}$ by XAFS and molecular dynamics calculations, and showed that $\mathrm{H}$ occupies tetrahedral sites of large icosahedra without significantly changing the local structure or coulombic oscillation. Their first principle calculation showed that amorphous alloy was $\mathrm{Ni}$-centered $\mathrm{Nb}$ triangle formed distorted icosahedra $\mathrm{Ni}_{5} \mathrm{Nb}_{3} \mathrm{Zr}_{5}$.

In 2013 Fujima et al. [67], using an established $\mathrm{N}_{5} \mathrm{Nb}_{3} \mathrm{Zr}_{5}$ icosahedral cluster model, constructed a 112-atom rhombohedral cell structure of amorphous $\mathrm{Ni}_{36} \mathrm{Nb}_{24} \mathrm{Zr}_{40}$. They suggested that $\mathrm{Nb}$ and $\mathrm{Ni}$ played very important role in restricting crystallization and maintaining the amorphous structure. According to their calculation, the icosahedral local structure was well maintained in the amorphous phase, and upon crystallization, forms a cuboctahedra.

Tokunaga et al. [68] employed thermodynamic modeling using CALPHAD methodology to determine the glassforming compositional region in the ternary $\mathrm{Ni}-\mathrm{Nb}-\mathrm{Zr}$ phase diagram; results were somewhat comparable with 
experimental results, but an order of magnitude lower than experimentally observed range. Density functional theory (DFT) calculations were reported as a reliable method for predictions of amorphous membranes for hydrogen permeation and purification by Hao and Sholl [69]. They performed DFT calculations on $\mathrm{Zr}_{36} \mathrm{Ni}_{64}$ and $\left(\mathrm{Ni}_{0.6} \mathrm{Nb}_{0.4}\right)_{70} \mathrm{Zr}_{30}$, and found that the experimental results of Hara et al [27] and Yamaura et al [46], and found reasonable agreement to their calculations, but the experimental permeabilities were reported as 2-4 times smaller than those calculated.

The Ni-Nb-Zr alloys are becoming more versatile, from the materials stand point of view, which not only have excellent permeation properties but have interesting electrical transport properties. Fukuhara et al. [70-72] reported, for the first time, semi conductivity, good electronic transport at room temperature, superconducting, electron avalanche and electric current coulomb oscillation in ternary $\left(\mathrm{Ni}_{0.60} \mathrm{Nb}_{0.40}\right)_{100-\mathrm{x}} \mathrm{Zr}_{\mathrm{x}}(\mathrm{x}=30-50)$ alloys with hydrogen. Fukuhara et al. [72, 73] studies were focused on measuring electrical resistivities of $\mathrm{Ni}_{36} \mathrm{Nb}_{24} \mathrm{Zr}_{40}$ and hydrogenated $\left(\mathrm{Ni}_{0.36} \mathrm{Nb}_{0.24} \mathrm{Zr}_{0.4}\right)_{90} \mathrm{H}_{10}$ alloy in $1.5 \mathrm{~K}$ to $300 \mathrm{~K}$ ranges. Experiments performed by decreasing temperatures, from $300 \mathrm{~K}$, revealed a sudden decrease in resistivity at $6 \mathrm{~K}$, and found superconductive (Type II) behavior at $2.1 \mathrm{~K}$. They also discussed effects of localization of hydrogen inside and in the vicinities of the icosahedral $\mathrm{Ni}_{5} \mathrm{Nb}_{3} \mathrm{Zr}_{5}$ cluster may have an impact on the properties.

Chandra et al. [74-75] performed atom probe tomography (APT) of $\left(\mathrm{Ni}_{0.60} \mathrm{Nb}_{0.40}\right)_{100-\mathrm{x}} \mathrm{Zr}_{\mathrm{x}}(\mathrm{x}=0-30$ at. $\%)$ and revealed the co-existence of three major amorphous phases: Phase $I$ (Ni-rich, considered as the matrix in the alloy), Phase II (Nb-rich) and Phase III ( $\mathrm{Zr}$-rich). We examined the sample $\mathrm{Ni}_{42} \mathrm{Nb}_{28} \mathrm{Zr}_{30}$ in the APT and found inhomogeneity in the amorphous phase of the membrane. The overall composition of the alloy is $\mathrm{Ni}_{42} \mathrm{Nb}_{28} \mathrm{Zr}_{30}$, but during glassy ribbon formation we found $\mathrm{Nb}$-rich clusters that have composition of $\mathrm{Ni}_{31.78} \mathrm{Nb}_{46.5} \mathrm{Zr}_{21.2}$, and $\mathrm{Zr}$ rich rich clusters of $\mathrm{Ni}_{38.64} \mathrm{Nb}_{17.9} \mathrm{Zr}_{43.45}$ which are significantly different than the overall composition of the alloy. To illustrate this, an APT 3D-construction and proximity concentration profile on a nanoscale of the $\mathrm{Ni}_{42} \mathrm{Nb}_{28} \mathrm{Zr}_{30}$ alloy in a $113 \times 109 \times 99 \mathrm{~nm}^{3}$ that shows all the atoms of Ni,Nb,Zr superimposed as dots (Figure 2(a)). In Figure 2(b), we show only $\mathrm{Nb}$-enriched atom clusters delineated by isoconcentration surfaces, and not showing $\mathrm{Ni}, \mathrm{Nb}$ or $\mathrm{Zr}$ atoms for clarity, whose average composition is $\mathrm{Ni}_{31.78} \mathrm{Nb}_{46.5} \mathrm{Zr}_{21.2}$ (green in color). A proxigram concentration profile was created averaging over all $\mathrm{Nb}$-enriched clusters, as schematically shown in the inset for one cluster. The proxigram (concentration vs. distance) shows the composition variation of the $93 \mathrm{Nb}$ and $58 \mathrm{Ni}$ isotopes detected using the mass spectrometer across a small line of $\sim 10 \mathrm{~nm}$ extending from point $\mathrm{A}$ to $\mathrm{C}$. The point $\mathrm{B}$ shows the interface at zero mark, i.e at the interface of the particle " $\mathrm{C}$ " and the matrix. As the scan approaches the interface the $\mathrm{Nb}$ concentration increases and that of $\mathrm{Ni}$ decreases. Based on previous research [63] we propose that these clusters are icosahedra type in these membranes. Other studies are in progress that relate to the dynamic aging studies [74-75] using inelastic neutron spectroscopy (INS) and x-ray correlation spectroscopy (XPCS).

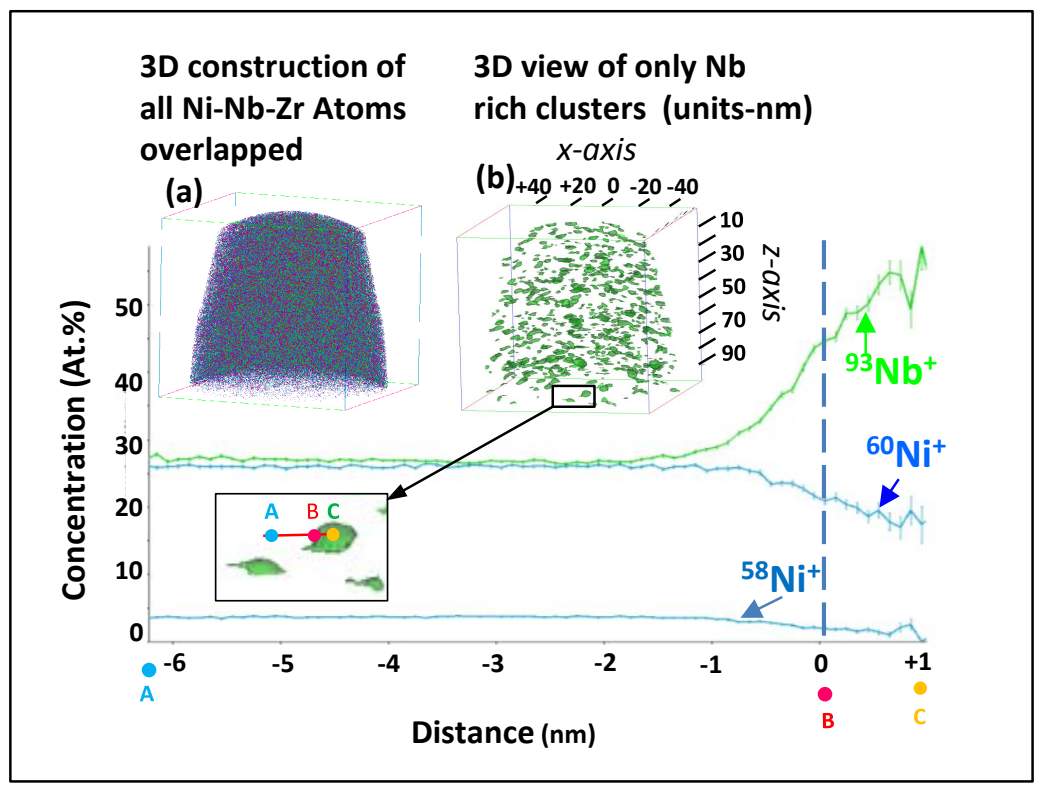

Figure 2(a) APT 3D-recons-
truction and proximity
concentration profile on a
nanoscale of the $\mathrm{Ni}_{42} \mathrm{Nb}_{28} \mathrm{Zr}_{30}$
alloy in a $113 \times 109 \times 99 \mathrm{~nm}^{3}$ cube
in which the atoms of $\mathrm{Ni}, \mathrm{Nb}$, and
$\mathrm{Zr}$ are displayed as dots. Figure
2(b) shows only the $\mathrm{Nb}$-enriched
clusters, delineated by an 34 at.\%
Nb isoconcentration surface, and
excluding Ni, (non-clustered) $\mathrm{Nb}$,
and $\mathrm{Zr}$ atoms for clarity. The
average composition of the $\mathrm{Nb}-$
rich clusters is Ni $31.78 \mathrm{Nb}_{46.5} \mathrm{Zr}_{21.2}$
(green in color), which is
significantly different from the
nominal overall alloy
composition.

This review illustrates our understanding of local atomic order in amorphous $\mathrm{Ni-Nb}-\mathrm{Zr}$ alloys is advancing, but the positioning of hydrogen atoms inside the icosahedra and it vicinity needs to explored. Neutron inelastic 
scattering is one tool which may provide useful information about the hydrogen positions in icosahedra clusters of these membranes.

\section{Summary}

Melt spun hydrogen-selective non-precious metal amorphous alloy membranes, such as $\left(\mathrm{Ni}_{60} \mathrm{Nb}_{40}\right)_{100-\mathrm{x}} \mathrm{Zr}_{\mathrm{x}}(\mathrm{x}=0$, 50 at \%) alloys, are emerging materials for $\mathrm{H}_{2} / \mathrm{CO}_{2}$ separation that are of industrial importance. Little was known until the last two decades or so, about the physical, local atomic order, mechanical, permeation, and electrical properties of these membranes. The research was perhaps driven by the high cost of Pd. We assembled the data from various studies and found that the permeabilities of these alloy vary in three orders of magnitude, from $1 \times 10^{-}$

${ }^{10}$ to $5 \times 10^{-8} \mathrm{~mol} \mathrm{~m}^{-1} \mathrm{~s}^{-1} \mathrm{~Pa}^{-0.5}$ with high hydrogen permeability between 473 and $673 \mathrm{~K}$, some of them are comparable to those of Pd- and Pd alloys. Gaining a greater understanding of local ordering which will assist in the development of highly permeable, durable alloy membranes we performed atom tomography that revealed $\mathrm{Nb}$ rich and Zr-rich amorphous clusters embedded in, majority Ni matrix, whose compositions deviated from the nominal composition of the membrane. More studies on lattice dynamics, such as inelastic neutron scattering, $\mathrm{x}$ ray correlation spectroscopy (XPCS) are in progress. More recently, Fukuhara et al. [72-73] measured electrical properties and reported exciting new findings on semi-conducting behavior at room temperature and superconducting behavior at very low temperatures. Based on all the above mentioned studies these alloys are not only useful for hydrogen permeation and may contribute in electronic industrial application.

\section{Acknowledgements}

This research is supported by US DOE-NNSA grant, (US DE-NA0002004).

\section{References}

1. N. E Amadeo, M. A. Laborde, Int. J. Hydrogen Energy, 20 12, 949-956 (1995).

2. S.-M. Kim, D. Chandra, N. Pal, M. Dolan, W-M Chien, J. Lamb, S. Paglieri and T. Flanagan, Int. J. Hydrogen Energy 37, 3904-3913 (2012).

3. C. Nishimura, M. Komaki, S. Hwang and M. Amano, J. Alloys Compd. 330-332, 902-906 (2002).

4. H. Hoang, H. Tong, F. Gielens, H. Jansen and M. Elwenspoek, Mater. Lett.58, 525-528 (2004).

5. M. Nishikawa, S. Shiraishi, Y. Kawamura and T. Takeishi, J. Nuclear. Sci. Technol, T33, 740-780 (1996).

6. Y. Guo, G. Lu, Y. Wang and R. Wang, Sep. Purif. Technol. 32, 271-279 (2003).

7. K. Yamakawa, M. Ege, B. Ludescher, M. Hirscher, H. Kronmuller, Journal of Alloys and Compounds $32117-$ $23(2001)$

8. K. Yamakawa, M. Ege, M. Hirscher, B. Ludescher, H. Kronmuller, Journal of Alloys and Compounds 393, 5-10 (2005)

9. K. Yamakawa, M. Ege, B. Ludescher, M. Hirscher, Journal of Alloys and Compounds 352, 57-59 (2003)

10. S. Paglieri and J.D. Way, Sep. Purif. Methods 31, 1-169 (2002).

11. S. A. Steward, Review of hydrogen isotope permeability through metals. US National Laboratory Report 1983:UCRL-53441.

12. W. Klement, R.H Willens, and P. Duwez, Nature 187, 869 (1960).

13. A. Inoue, T. Zhang, T. Masumoto, Mater. Trans. JIM 33, 965 (1989).

14. A. Inoue, Acta Mater. 48, 279 (2000).

15. M. Baricco and M. Palumbo, Advanced Engineering Materials, Special Issue-bulk metallic glasses, Volume 9, Issue 6, pages 454-467, June, 2007

16. J. W. Phair and R. Donelson, Ind. Eng. Chem. Res. 45, 5657-5674 (2006).

17. J. W. Phair and S.P.S Badwal, Sci. Technol. Adv. Mater. 7, 792-805 (2006).

18. M. D. Dolan, N. C. Dave, A. Y. Ilyushechkin, L. D. Morpeth and K. G. McLennan, J. Membr. Sci. 285, 3055 (2006).

19. N.W. Ockwig, T.M Nenoff, Chem. Rev. 107, 4078-4110 (2007).

20. F.H.M. Spit, J.W. Drijver, W.C. Turkenburg, S. Radelaar, G. Bambakidis (Ed.), Metal Hydrides, Plenum, New York, 345-360 (1981).

21. K. Aoki, A. Horata, T. Masumoto: Proc. 4th Int. Conf. on Rapidly Quenched Metals 1649 (1981).

22. R.W Lin, H. H. Johnson, J. Non-Cryst. Solids 51, 45-56 (1983).

23. G. Adachi, H. Nagai, J. Shiokawa, J. Less-Common Met. 149, 185-191 (1989).

24. J. O. Stroem-Olsen, Y. Zhao, D. H Ryan, Y. Huai, R.W. Cochrane, J. Less-Common Met. 172-174, 92292728 (1991).

25. O. Yoshinari, R. Kirchheim, J. Less-Common Met. 172-174, 890-898 (1991).

26. S. L. I Chan, C. I. Chiang, J. Alloy. Compd. 253-254, 370- 373 (1997).

27. S. Hara, K. Sakaki, N. Itoh, H-M. Kimura, K. Asami, A. Inoue, J. Membr. Sci. 164, 289-294 (2000). 
28. H. Kimura, A. Inoue, S-I.Yamaura, K. Sasamori, M. Nishida, Y. Shinpo, H. Okouchi, Mater. Trans. JIM 44, 1167-1171 (2003).

29. S-I Yamaura, Y. Shimpo, H. Okouchi, M. Nishida, O. Kajita, H. Kimura, A. Inoue, Mater. Trans. JIM 44, 1885-1890 (2003).

30. S. Hara, N. Hatakeyama, N. Itoh, H.-M. Kimura, A. Inoue, Desalination 144, 115-120 (2002).

31. S. Hara, N. Hatakeyama, N. Itoh, H.-M. Kimura, A. Inoue, J. Membr. Sci. 211, 149-156 (2003).

32. S-I Yamaura, Y. Shimpo, H. Okouchi, M. Nishida, O. Kajita, A. Inoue, Mater. Trans. JIM 45, 330-333 (2004).

33. S-I Yamaura, S. Nakata, H. Kimura, Y. Shimpo, M. Nishida and A. Inoue, Materials Transactions, 46, 8 , 1768$1770(2005)$

34. K. Ishikawa, T. Takano, T. Matsuda, K. Aoki, Appl. Phys. Lett. 87, 081906 (2005).

35. Y. Shimpo, S-I Yamaura, M. Nishida, H. Kimura, A. Inoue, J. Membr. Sci. 286, 170-173(2006).

36. S-I Yamaura, S. Nakata, H. Kimura, A. Inoue, Mater. Trans. JIM 47, 2991 - 2996 (2006).

37. K. B. Kim, K. D. Kim, D. Y. Lee, Y. C. Kim, E. Fleury, D. H. Kim, Mater. Sci. Eng. A 449-451, 934-936 (2007).

38. S.Hara, H-X Huang, M. Ishitsuka, M. Mukaida, K. Haraya, N. Itoh, K. Kita, K. Kato, J. Alloy Compd. 458, 307-312 (2008).

39. S. Hara, M. Ishitsuka, H. Suda, M. Mukaida, and K. Haraya, J. Phys. Chem. B 113, 9795-9801 (2009).

40. D-Y Lee and E. Fleury, Met. Mater. Int. 14, 545-548 (2008).

41. J. B. Qiang, W. Zhang, S. Yamaura, A. Inoue, Mater. Trans. JIM, 50, 1236-1239 (2009).

42. M. D. Dolan, N. C. Dave, L. D. Morpeth, R. Donelson, D. Liang, M. E. Kellam, S. Song, J. Membr. Sci. 326, 549-555 (2009).

43. M.D. Dolan, S. Hara, N. C. Dave, K. Haraya, M. Ishitsuka, K. Kita, K. G. McLennan, L. D. Morpeth, M. Mukaida, Sep. Purif. Technol. 65, 298-304 (2009).

44. D. M. Viano, M. D. Dolan, F, Weiss, A. Adibhatla, J. Membr. Sci. 487, 83-89 (2015).

45. A. Adibhatla, M. D. Dolan, W. Chien, D. Chandra, J. Membr. Sci. 463, 190-195 (2014).

46. H. Y. Ding, W. Zhang, S. I. Yamaura, K. F. Yao, Mater. Trans. JIM 54, 1330-1334 (2013).

47. S. Paglieri, N. Pal, M. Dolan, S. Kim and W. Chien, J. Membr. Sci. 378, $42-50$ (2011).

48. R.E. Buxbaum, T.L. Marker, J. Membr. Sci. 85, 29-38 (1993).

49. S-I Yamaura, A. Inoue, J. Membr. Sci. 349, 138-144 (2010).

50. A.E. Lewis, H. Zhao, H. Syed, C. A. Wolden, J. D. Way, J. Membr. Sci. 465, 167-176 (2014).

51. W.C. Chian, W.D. Yeh, J.K. Wu, Mater. Lett. 59 2542-2544 (2005).

52. H.E. Kissinger, Anal. Chem. 29 (1957) 1702.

53. T. Ozawa, J. Therm. Anal. 2 (1970) 301.

54. S-M Kim, W-M Chien, D. Chandra, N. K. Pal, A. Talekar, J .Lamb, M.D. Dolan, S.N. Paglieri, T.B. Flanagan, J. Non-Cryst. Solids 358, 1165-1170 (2012).

55. S. Jayalakshmi, Y.G. Choi, Y.C. Kim, Y.B. Kim, E. Fleury, Intermetallics, 18, 1988-1993 (2010)

56. S. Jayalakshmi, V.S. Vasantha, E. Fleury, M. Gupta, Appl. Energy 90, 94-99 (2012).

57. S. Jayalakshmi, S.O. Park, K.B. Kima, E. Fleury, D.H. Kim, Mat. Sci. Eng. A 449-451, 920-923 (2007).

58. Y. Zhao, I-C Choi, M-Y Seok, U. Ramamurty, J-Suh, J-I Jang, Scripta Mater. 93, 56-59 (2014).

59. Y. Zhao, I-C Choi, M-Y Seok, M-H Kim, D-H Kim, U. Ramamurty, J-Suh, J-I Jang, Acta Mater. 78, $213-221$ (2014).

60. O. Palumbo, S. Brutti, F. Trequattrini, S. Sarker, M. Dolan, D. Chandra, A. Paolone, Energies 8, 3944-3954 (2015); doi:10.3390/en8053944.

61. S-I. Yamaura, M. Sakurai, M. Hasegawa and K. Wakoh, Acta Mater. 53, 3703-3711 (2005).

62. M. Sakurai, S. Yamaura, K. Wakoh, E. Matsubara A. Inoue, J. Metastable Nanocryst. Mater. 24-25, 551-554 (2005).

63. H. Oji, K. Handa, J. Ide, T. Honma, N. Umesaki, S. Yamaura, M. Fukuhara, A. Inoue S. Emura, J. Phys: Conference Series 190, 012075-1 -012075-4 (2009).

64. H. Oji, K. Handa, J. Ide, T. Honma, S. Yamaura, A. Inoue, N. Umesaki, J. Appl. Phys. 105, 113527-1-1135276 (2010).

65. M. Fukuhara, N. Fujima, H. Oji, A. Inoue, S. Emura, J. Alloy Compd. 497, 182-187 (2010).

66. M. Matsuura, M. Fukuhara, K. Konno, T. Fujita, M.W. Chen, N. Fujima, A. Inoue, J. Non-Cryst. Solids 357 , 3357-3360 (2011).

67. N. Fujima, T. Hoshino, M. Fukuhara, J. Appl. Phys. 114, 063501-1- 063501-9 (2013).

68. T. Tokunaga, S. Matsumoto, H.Ohtani, M. Haesebe, Mater. Trans. JIM 48, 2263-2271 (2007).

69. S. Hao, D. S. Sholl, J. Membr. Sci. 350, 402-409 (2010).

70. M. Fukuhara, A. Inoue, Physica B 3630-3622, (2010)

71. M. Fukuhara, A. Inoue, J. Appl. Phys. 105, 063715 (2009). 
Manuscript Submitted to IEA Special Issue (10-30-2015) - Journal of Applied Physics A.

72. M. Fukuhara, H. Yoshida, K. Koyama, A. Inoue, Y. Miura, J. Appl. Phys. 107, 03370 1-5 (2010) .

73. M. Fukuhara, H. Yoshida, A. Inoue, N. Fujima, Intermetallic 80, 1864-1866 (2010).

74. D. Chandra, Behavior of Ni-Nb-Zr Alloy Gas Permeation Membrane Ribbons at Extreme Pressure Condition, US DOE Contract No. DE-NA0002004 May 13, (2014).

75. D. Chandra, Behavior of Ni-Nb-Zr Alloy Gas Permeation Membrane Ribbons at Extreme Pressure Condition, USDOE Contract No. DE-NA0002004 August 18, (2015). 